Dejana Pavlović ${ }^{1}$ Jovan Zubović ${ }^{2}$

Aleksandar Zdravković ${ }^{3}$
JEL: J21, J28, J88, E24

DOI: 10.5937/industrija44-12784

UDC: 331.526-053.6(4)

Original Scientific Paper

\title{
Youth Expectations in Job Search in Serbia ${ }^{4}$
}

\author{
Article history: \\ Received: 2 September 2016 \\ Sent for revision: 22 September 2016 \\ Received in revised form: 2 November 2016 \\ Accepted: 12 November 2016 \\ Available online: 30 December 2016
}

\begin{abstract}
Youth on the labour market in developing countries such as Serbia, Macedonia, Bosnia and Herzegovina are facing numerous difficulties, with almost a half of their population aged between 15-24 not working or working in informal sector. The reasons may be numerous. The financial crisis and the low economic development of the country have had negative impact on young generations and this resulted in lack of sufficient jobs vacancies. In addition, the reasons for their slow entry into the labour market could be the lack of experience, low education among young people etc. Although employers have certain expectations of young people, once they enter the labour market young people have certain values that are important for them when choosing a job. The paper presents the research on the expectations of young people entering labour market in the Republic of Serbia. According to survey results based on analyses of youth' expectations and preferences in Serbia regarding potential work conditions, authors have by the means of factor analysis identified which groups of factors are the most important for young people ages between 16 and 30 in job finding in Serbia. The results showed that there is a significance of three questions: 1 . Job does not affect the private life; 2. Work resources are provided; 3. Work is safe. In conclusion, if a company ensures that these three issues are regulated, it will more likely employ young professionals.
\end{abstract}

Keywords: Unemployment, Youth in Labour Market, Factor Analysis.

\footnotetext{
${ }^{1}$ Institute of Economic Sciences, Belgrade, dejana.pavlovic@ien.bg.ac.rs

2 Institute of Economic Sciences, Belgrade

${ }^{3}$ Institute of Economic Sciences, Belgrade

4 The paper presents the results of a study conducted as a part of the projects: no.179001 and 179015, funded by the Ministry of Education, Science and Technological Development, Republic of Serbia.
} 


\title{
Očekivanja u pogledu uslova rada pri zapošljavanju mladih u Srbiji
}

\begin{abstract}
Abstrakt: Mladi na tržištu rada zemalja u razvoju, kao što su Srbija, Makedonija, Bosna i Hercegovina, se suočavaju sa brojnim poteškoćama, kao što je da skoro polovina stanovništva starosti između 15 -24 ne radi ili rade $u$ neformalnom sektoru. Razlozi za to mogu biti brojni. Finansijska kriza i nizak ekonomski razvoj zemlje su negativno uticali na mlade generacije što je rezultiralo nedostatkom slobodnih radnih mesta. Pored toga, kao razlozi za njihov otežan ulazak na tržište rada navode se nedostatak iskustva, nizak stepen obrazovanja među mladima itd. Kako poslodavci imaju određena očekivanja od mladih ljudi kad ulaze na tržište rada, tako i mladi imaju određene kriterijume koji su im važni pri odabiru posla. U radu je prikazano istraživanje o očekivanjima mladih ljudi koji ulaze na tržište rada u Republici Srbiji. Prema rezultatima istraživanja na osnovu analize očekivanja mladih $i$ potreba $u$ vezi sa potencijalnim uslovima rada, autori su primenom faktorske analize identifikovali koje su grupe faktora najvažnije u pronalaženju radnog mesta u Srbiji, sa fokusom na nezaposlene mlade osobe uzrasta između 16 i 30 godina. Rezultati su pokazali da su im najznačajnija tri pitanja: 1. da posao ne utiču na privatan život; 2. da su sredstva obezbeđena; 3 . da je posao siguran. Na kraju dolazimo do zaključka da ako kompanija obezbedi da su ova tri pitanja regulisana, veća je verovatnoća da će zaposliti mlade profesionalce.
\end{abstract}

Ključne reči: nezaposlenost, mladi na tržištu rada, faktorska analiza.

\section{Introduction}

The negative impact of the financial crisis has put young people in disadvantage on the labor market, and therefore certain indicators, such as unemployment rate, are even twice as high among young people than in adults. The issue of high unemployment rate arises not only in developing countries but also at the global level. Therefore, this area of research has become increasingly popular among researchers in the world.

The paper is focused on unemployed young people ages between 16 and 30 , and it analyzed their expectations in job search in the Republic of Serbia. The paper used factor analysis in order to establish the factors that impact the young people's expectations the most when entering the labor market. Factor analysis, which is a method of multivariate analysis, is used in case of a large number of variables to be implemented on a lower number of variables, called factors (Kovacic, 1994). 
In the past few years, the Republic of Serbia was facing the high unemployment rate among young people and low activity rate of young people, ages 15 to 24 . More specifically, since 2008, the unemployment rate among young people ages 15 to 24 has been ranging from $35.2 \%$ to $51.1 \%$ in 2012, and by the end of 2015 it fell to $43 \%$ (Statistical Office of Republic of Serbia, 2015).

However, according to the results of the research conducted by the International Labor Organization, poverty among young people is not present only in developing countries, but also globally. According to data from 2013, two out of five active young people were unemployed or employed but living in poverty, while about $37 \%$ of employed young people live on less than 2 dollars a day (Global Employment Trends for Youth, ILO, 2013).

Large number of applicants for new jobs, low chances for getting a permanent job, and the adverse impact of economic factors led to the fact that nowadays it is not easy to be young (Global Employment Trends for Youth, ILO, 2013). On the other hand, apart from a small number of vacancies in the market, young people are struggling with the problem of lack of professional experience. There is no doubt that employers give more opportunities to person with previous work experience (Parey, 2009). The current situation in Serbia shows that the system of apprenticeships has not yet taken hold and young people are denied the opportunity to gain practical experience during their education. On the other hand, in developed countries, professional training and obtaining a new work experience has a significant impact on the increase in earnings among young (Flinn, 2006). Researchers believe that the post-school professional training is an essential source of knowledge. According to Heckman, Lochner and Taber (1998), post-school education makes $30 \%$ to $50 \%$ of the total knowledge in the modern economy. According to the model of the labor market research by Gorry (2013), the results showed that interaction between experience and minimum wages effect the unemployment rate among young people. Research conducted by Gorry based on the research from the ' $80 \mathrm{~s}$, recognized the impact of minimum wage on human capital (Rosen, 1972). The results show that workers without previous experience are not able to pay for additional professional training. Therefore, in order to gain experience, they remain to be employed in one segment of the labor market which leads to high job separation rates.

Modern economy is based on knowledge as a key resource. Strategic investments in human resource development is an important indicator of development of a country, while wealth and natural resources are observed to a lesser extent (Pržulj, 2009).

The paper presents the research conducted in Serbia, where the survey covered 150 unemployed young people aged 16 to 30 . Respondents were taken from SILC survey conducted by the Republic Statistical Office of the 
Pavlović D. et al.: Youth Expectations in Job Search in Serbia

Republic of Serbia. The research provides the answer to three key research questions:

Which factors are essential for reducing youth turnover in companies?

Is salary the only factor important for hiring young employees?

To what extent do opportunities for professional training affect the attractiveness of job among young people in Serbia?

The first part of the paper shows position of young people on the labor market and review of previous research on employment of young people as well as their expectations. The second part of the paper presents the methodology of the research and interpretation of results. The final part of the paper contains discussion and conclusion.

\section{Literature review}

The focus of any organization is a human, as its creator and member. Taking into account the complexity of a man and his behaviour, we come to the conclusion that an organization is very complex too. To eliminate dissatisfaction among employees, it is necessary to evaluate the degree of job satisfaction because it will enable clear information about the parameters that are essential for meeting the common objective.

Among the first studies of the last century, the author of the Expectation Confirmation Theory, Richard Oliver, shows that the lower expectations from employment, the greater chances for higher job satisfaction (Oliver, 1980). After the Expectation Confirmation Theory, several studies were tested and proven that emphasized that employees' expectations depend on many factors such as previous experience (Maister, 1985), earnings (Evenson, 2005), the attitude of an individual (Maister, 1985, Bowen, 2001), as well as the business operation of a company (Fretwell, Goldberg, 1993).

However, if we focus on expectations of young employees without previous experience, we can see that their expectations are based on the experience of others (Markuš, 2013). The behaviour of people in organizations, i.e. at their workplace, is greatly influenced by feelings and formal attitudes (Djilas, 2010). Organizational commitment and job satisfaction are directly related to the company's profitability and competitive position in the market. The aforementioned directly affects employees, and therefore this issue is considered of great importance (llie, Judge, 2002). Behaviour of seniors largely determines the perception of organizational support and the perception of certain characteristics of work by employees, such as employees' perceptions about the degree of autonomy in their work, the complexity of the 
work role and the degree of challenging demand of work (Cummings, 1978). According to Griffin (1979), the behavior of leaders is one of the moderators of the correlation between the "job characteristics" variable, on one hand, and the "performance of employees" and "job satisfaction" variables, on the other hand. In his later studies, the same author emphasizes that change in senior's behaviour can influence the perception of job characteristics (Griffin, 1981). A well-known expert in the field of organizational behaviour, Luthans believes that managers cannot be considered effective, unless they have satisfied and dedicated employees to whom they are superiors (Luthans, 1988). In the literature in the field of management and social sciences, job satisfaction is linked to behaviour in the workplace, including absenteeism, organizational commitment and productivity. Therefore, it is not surprising that numerous studies emphasize the importance of identifying determinants of expectations and job satisfaction (Georgellis, Lange and Tabvuma, 2012).

Figure 1 Study on employees' dissatisfaction

\begin{tabular}{|c|c|c|c|}
\hline \multicolumn{4}{|c|}{ Activity } \\
\hline \multirow{2}{*}{ Destructiveness } & Exit & Voice & \multirow{2}{*}{ Constructiveness } \\
\hline & Neglect & Loyalty & \\
\hline
\end{tabular}

Source: Robbins, 1993.

Figure 1 presents four answers to dissatisfaction, which differ according to two dimensions: constructiveness / destructiveness and activity/passivity. One can see that dissatisfied employees leave the company or create a bad climate in the business. Employees' satisfaction is a simple model. If employees' expectations are met or exceeded, client is satisfied. However, vice versa employees will not be satisfied, and will look for a job elsewhere (Markuš, 2013). Dissatisfied employees affect company's business. Identifying expectations of new employees represents an essential part of organizational management for company positioning.

\section{Methodology}

The paper presents the results of the survey conducted in Serbia on a sample of 150 respondents (sub-sample of the SILC survey conducted in 2014). The 
questionnaire covered the unemployed of both sexes, different ages, different education, young people aged 16 - 30 .

Figure 2. Characteristics of respondents

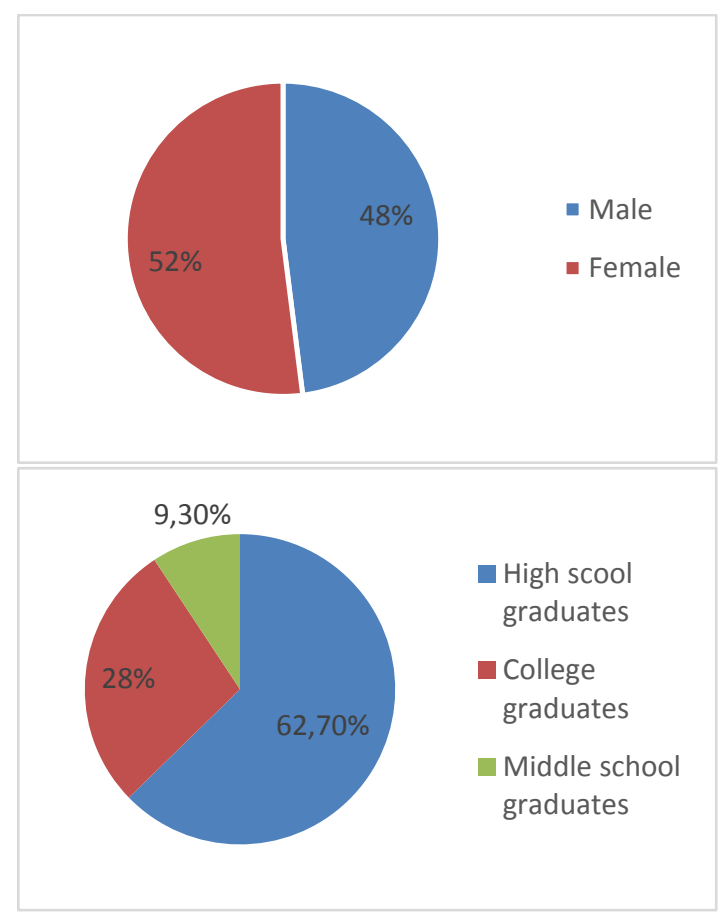

Source: Own calculations

Respondents were asked about their expectations when entering the labour market. In survey we used the Likert Scale. Respondents are offered on fivepoint scale to show how much they agree (max value is 1) or disagree (min value is 5) with statement. Summary results of the answers are shown in the table below.

According to the answers on expectations provided by young unemployed people while searching for job, the highest number of positive responses is observed for question on whether employment is permanent, which is linked to past times and probably to employment in the public sector, but it can also be a factor for obtaining bank loans, etc. On the other hand, organized gatherings at work is a less important factor influencing the expectations of young people. 
Pavlović D. et al.: Youth Expectations in Job Search in Serbia

Table 1. Research results on the SILC survey subsample covering 150 unemployed people aged 16 - 30

\begin{tabular}{|l|l|l|}
\hline Question & Avg. & Stdev. \\
\hline Training is provided at work & 1,85 & 0,75 \\
\hline Permanent employment & 1,54 & 0,63 \\
\hline Dynamic work & 2,3 & 0,89 \\
\hline $\begin{array}{l}\text { Presentation of ideas and remarks to superiors is } \\
\text { supported }\end{array}$ & 2,21 & 0,75 \\
\hline Mentor is provided at work & 2,33 & 0,9 \\
\hline Employees' obligations are clear & 1,67 & 0,56 \\
\hline Job does not affect the private life & 2,11 & 0,93 \\
\hline Managers are highly educated people & 2,27 & 1,1 \\
\hline Gathering of co-workers is organized every year & 2,67 & 1,01 \\
\hline Feedback on the quality of your work & 1,81 & 0,57 \\
\hline Teamwork is encouraged & 1,87 & 0,6 \\
\hline Above-average earnings & 2,53 & 0,93 \\
\hline Employee incentives and benefits & 2,11 & 0,78 \\
\hline Work resources are provided & 1,7 & 0,5 \\
\hline Work is safe (physically) & 1,57 & 0,6 \\
\hline Promotion is available to all & 1,76 & 0,53 \\
\hline
\end{tabular}

\section{Results and discussion}

The first step of the research requires the processing of the results by KMO and Bartlett's Test to determine that our set of answers is satisfactory for factor analysis. The value of Kaiser-Meyer-Olkin measure, which ranges from 0 to 1 , is calculated using the following formula:

$$
k_{i}=\frac{\sum_{\substack{k=1 \\ k \neq i}}^{p} r_{i k}^{2}}{\sum_{\substack{k=1 \\ k \neq i}}^{p} r_{i k}^{2}+\sum_{\substack{k=1 \\ k \neq i}}^{p} q_{i k}^{2}}, \quad 0 \leq k_{i} \leq 1, i=1,2 \ldots p .
$$

If the value is less than 0.5 then the set is not suitable for factor analysis (Stewart, 1981). According to the results of the KMO, the adequacy value of the sample is greater than 0.5 and is 0.746 . In the Bartlett's sphericity test, realized value is $p=0.000$, which confirms that the data show some degree of correlation, which will enable their collection and formation of factors. 
Pavlović D. et al.: Youth Expectations in Job Search in Serbia

Table 2. KMO and Bartlett's Test

\begin{tabular}{|c|c|c|}
\hline \multicolumn{2}{|c|}{ Kaiser-Meyer-Olkin Measure of Sampling Adequacy. } & ,746 \\
\hline \multirow{3}{*}{ Bartlett's Test of Sphericity } & Approx. Chi-Square & 388,935 \\
\hline & df & 120 \\
\hline & Sig. &, 000 \\
\hline
\end{tabular}

Source: Authors calculations

Based on the presentation of results of correlation matrix, which is obtained by using factorial test in SPPS software package, a number of correlation coefficients greater than 0.3 were found, and thus the conditions for the start of Principal Component Analysis are fulfilled.

Table 3. Total Variance Explained

\begin{tabular}{|c|c|c|c|c|c|c|}
\hline & \multicolumn{5}{|c|}{ Initial Eigenvalues } & \multicolumn{3}{c|}{ Extraction Sums of Squared Loadings } \\
\cline { 2 - 7 } & Total & \% of Variance & Cumulative \% & Total & $\%$ of Variance & Cumulative \% \\
\hline 1 & 3,615 & 22,591 & 22,591 & 3,615 & 22,591 & 22,591 \\
\hline 2 & 1,512 & 9,452 & 32,043 & 1,512 & 9,452 & 32,043 \\
\hline 3 & 1,321 & 8,256 & 40,298 & 1,321 & 8,256 & 40,298 \\
\hline 4 & 1,101 & 6,884 & 47,183 & 1,101 & 6,884 & 47,183 \\
\hline 5 & 1,036 & 6,477 & 53,659 & 1,036 & 6,477 & 53,659 \\
\hline 6 & 1,003 & 6,270 & 59,929 & 1,003 & 6,270 & 59,929 \\
\hline 7 &, 977 & 6,108 & 66,037 & & & \\
\hline 8 &, 792 & 4,953 & 70,990 & & & \\
\hline 9 &, 761 & 4,755 & 75,745 & & & \\
\hline 10 &, 731 & 4,569 & 80,314 & & & \\
\hline 11 &, 692 & 4,325 & 84,639 & & & \\
\hline 12 &, 643 & 4,016 & 88,655 & & & \\
\hline 13 &, 520 & 3,252 & 91,907 & & & \\
\hline 14 &, 467 & 2,920 & 94,826 & & & \\
\hline 15 &, 439 & 2,746 & 97,572 & & & \\
\hline 16 &, 388 & 2,428 & 100,000 & & & \\
\hline
\end{tabular}

Extraction Method: Principal Component Analysis.

The application of the Initial Eigenvalues method resulted in the need to generate 6 factors, given that there are 6 factors on the basis of eigenvalue greater than 1. Table 3 shows the value of variance for each factor, which is calculated based on the total value of the eigenvalue $(\lambda j)$ divided by the total number of indicators $(p)$ and multiplied by one hundred. The formula for calculating the variance: 
Pavlović D. et al.: Youth Expectations in Job Search in Serbia

$$
p \mathrm{j}=\frac{\lambda j}{p} * 100, j=1,2,3 \ldots . m
$$

Calculation of the variance of the first factor is equal to:

$$
\mathrm{p}_{\mathrm{j}}=\frac{3,615}{16} * 100=22,59
$$

In social sciences, the variance value is taken into account up to $60 \%$ (which in this case includes the first six factors), while in natural sciences it goes up to $95 \%$ (Hair et al., 1998).

Next step required to determine which variable belongs to which factor. Results of the rotated component matrix clearly showed which variables grouped which factors.

Table 4. Rotated Component Matrix

\begin{tabular}{|l|c|c|c|c|c|c|}
\hline & \multicolumn{5}{|c|}{ Component } \\
\cline { 2 - 6 } & 1 & 2 & 3 & 4 & 5 & 6 \\
\hline Training is provided at work &, 713 & & & & & \\
\hline $\begin{array}{l}\text { Presentation of ideas and remarks to } \\
\text { superiors is supported }\end{array}$ &, 547 & & & & & \\
\hline Mentor is provided at work &, 717 & & & & & \\
\hline $\begin{array}{l}\text { Gathering of co-workers is organized every } \\
\text { year }\end{array}$ & & &, 635 & & & \\
\hline Permanent employment & & &, 642 & & & \\
\hline Employees' obligations are clear & & &, 588 & & & \\
\hline Dynamic work & & & &, 504 & & \\
\hline Managers are highly educated people & & & &, 526 & & \\
\hline Feedback on the quality of your work & & & &, 772 & & \\
\hline Above-average earnings & &, 685 & & & & \\
\hline Employee incentives and benefits & &, 753 & & & & \\
\hline Job does not affect the private life & & & & &, 738 & \\
\hline Work resources are provided & & & & &, 579 & \\
\hline Work is safe (physically) & & & & &, 570 & \\
\hline Teamwork is encouraged & & & & & &, 769 \\
\hline Promotion is available to all & & & & &, 597 \\
\hline
\end{tabular}

Extraction Method: Principal Component Analysis.

Rotation Method: Varimax with Kaiser Normalization. a. Rotation converged in 12 iterations.

Factor 1: Training is provided at work, Presentation of ideas and remarks to superiors is supported, Mentor is provided at work.

Factor 2: Employee incentives and benefits and Above-average earnings. 
Pavlović D. et al.: Youth Expectations in Job Search in Serbia

Factor 3: Gathering of co-workers is organized every year, Permanent employment and Employees' obligations are clear.

Factor 4: Managers are highly educated people, Feedback on the quality of your work and Dynamic work.

Factor 5: Job does not affect the private life Work resources are provided Work is safe.

Factor 6: Teamwork is encouraged and Promotion is available to all.

From the factor analysis, we grouped six factors placed in the regression with the dependent variable "How do young people assess whether they will be employed over the next six months". R2 is low, which is justified given that it is below $50 \%$ for the prediction of human behaviour (Stewart, 1981). The result is that there is a significance of factor 5 comprising the following three questions:

- Job does not affect the private life;

- Work resources are provided

- Work is safe.

If a company ensures that these three issues are regulated, it will more likely employ young professionals.

\section{Conclusion}

The results of the factor analysis contribute to solving problems in various areas of business. Factor analysis was performed in the study in order to solve the problem of high unemployment among young people in Serbia. The issue of the high unemployment rate is one of the most pressing problems. It is increasingly difficult for young people to access the labour market. One reason is the fulfilment of high criteria for their employment.

As employers have certain criteria, in the same way young people take into account factors that are important to them for entering the labour market. Having observed a particular group of factors and applied the factor analysis, we got answers to the following research questions:

For the question "Which factors are essential for reducing youth turnover in companies?", the results of the factor analysis identified the following indicators: 1. Job does not affect the private life, 2. Work resources are provided and 3 . Work is safe. If a company ensures that these three issues are regulated, it will more likely employ young professionals. 
For the question "Is salary the only factor important for hiring young employees?", from the factor analysis we can see that the econometric models show that salary is not an important factor for employment of people younger than 30. Furthermore, in Table 1, according to the young people's answers, we can see that above-average salary is less important factor. According to this study, the young would prefer learning and training over high earnings at the beginning of their career, which was confirmed by answer to the question: To what extent do opportunities for professional training affect the attractiveness of job among young people in Serbia?

The research results could be used by decision-makers for defining strategies that affect young people and in the field of labour market.

\section{Literature}

Bowen, D. (2001). Antecedents of consumer satisfaction and dis-satisfaction (CS/D) on long-haul inclusive tours a reality check on theoretical considerations, Tourism Management 22, pp. 49. - 61.

Cummings, T. G. (1978). Self-regulating work groups: a socio-technical synthesis. Academy of Management Review, vol. 3, 625-634.

Djilas, S.(2010). Odnos zaposlenih prema poslu u organizaciji. Zbornik radova Fakulteta tehničkoh nauka, Novi Sad.

Evenson, R. (2005). Customer Service Training 101: Quick and Easy Techniques That Get Great Results. Saranac, Lake: AMACOM Books.

Flinn, C.J. (2006). Minimum wage effects on labor market outcomes under search, matching, and endogenous contact rates. Econometrical, 74, 1013-1062.

Fretwell, D., Goldberg, S. (1993). Developing Effective Employment Services. World Bank Discussion Papers, No.208, Washington, D.C., World Bank

Global Employment Trends (2013). International Labor Organization. Retrieved from http://www.ilo.org/wcmsp5/groups/public/---dgreports/--dcomm/documents/publication/wcms 212423.pdf

Gorry, A. (2013), Minimum wages and youth unemployment, European Economic Review, vol. 64, pp.57-75.

Griffin, R. W. (1979). Task design determinants of effective leader behavior. Academy of Management Review, 4, 215-224.

Griffin, R. W. (1981). Supervisory behavior as a source of perceived task scope. Journal of Occupational Psychology, vol. 54, 175-182.

Hair, J. F., R. E. Anderson, R. L. Tatham and W. Black (1998). Multivariate Data Analysis. Englewood Cliffs, Prentice Hall, 5th Ed.

Heckman J.,Lecher L.,Tabor C. (1998). Explaining Rising Wage Inequuality, Explorations With a Dynamic General Equilibrium Model of Earnings with Heterogeneous Agents, Review of Economic Dynamics, vol 1.

Kovačić, Z. (1994). Multivarijaciona analiza, Ekonomski fakultet, Beograd.

Luthans F. (1988). Successful vs. effective real manager. Academy of Management Executive, 2, 127-132. 
Pavlović D. et al.: Youth Expectations in Job Search in Serbia

Maister, D.H. (1985). The psychology of waiting lines, The Service Encounter, Lexington Books/DC Heath, London.

Markuš, R. (2013), Customer survey in public employment services: Expectations vs. Satisfaction, Ekonomski Vjesnik, Bosna I Hercegovina

Oliver, R. L. A (1980). Cognitive Model of the Antecedents and Consequences of Satisfaction Decisions. Journal of Marketing Research 17, pp. 460. - 469

Parey, M. (2009). Vocational Schooling versus Apprenticeship Training: Evidence from Vacancy Data. Unpublished manuscript

Pržulj, Ž. (2009). Uloga menadžmenta ljudskih resursa u ekonomiji znanja, Scientific conference "Na putu ka dobu znanja", Split, Croatia.

Robbins, S. (1993). Organizational behavior (Concept, contoversies and applications). San Diego State University, sixth edition, page 36.

Rosen, S., 1972. Learning and experience in the labor market. The Journal of Human Resources 7 (Summer (3)), 326-342

Statistical Office of the Republic of Serbia. (2015). Rates of activity, employment, inactivity and unemployment. Retrieved from http://webrzs.stat.gov.rs/WebSite/

Stewart, D. W. (1981). The Application and Misapplication of Factor Analysis in Marke ting Research, Journal of Marketing Research, 18: 51-62. 